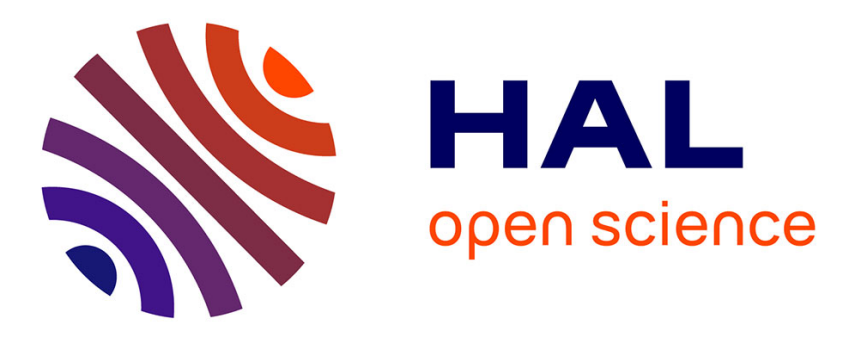

\title{
Influence of calf presence during milking on yield, composition, fatty acid profile and lipolytic system of milk in Prim'Holstein and Salers cow breeds
}

Anamaria Cozma, Bruno Martin, Marlène Guiadeur, Philippe Pradel, Emilie Tixier, Anne Ferlay

\section{To cite this version:}

Anamaria Cozma, Bruno Martin, Marlène Guiadeur, Philippe Pradel, Emilie Tixier, et al.. Influence of calf presence during milking on yield, composition, fatty acid profile and lipolytic system of milk in Prim'Holstein and Salers cow breeds. Dairy Science \& Technology, 2013, 93 (1), pp.99-113. 10.1007/s13594-012-0094-1. hal-01201413

\section{HAL Id: hal-01201413 \\ https://hal.science/hal-01201413}

Submitted on 17 Sep 2015

HAL is a multi-disciplinary open access archive for the deposit and dissemination of scientific research documents, whether they are published or not. The documents may come from teaching and research institutions in France or abroad, or from public or private research centers.
L'archive ouverte pluridisciplinaire HAL, est destinée au dépôt et à la diffusion de documents scientifiques de niveau recherche, publiés ou non, émanant des établissements d'enseignement et de recherche français ou étrangers, des laboratoires publics ou privés. 


\title{
Influence of calf presence during milking on yield, composition, fatty acid profile and lipolytic system of milk in Prim'Holstein and Salers cow breeds
}

\author{
Anamaria Cozma • Bruno Martin • Marlène Guiadeur • \\ Philippe Pradel $\cdot$ Emilie Tixier $\cdot$ Anne Ferlay
}

Received: 19 June 2012 /Revised: 27 October 2012 / Accepted: 5 November 2012 /

Published online: 20 December 2012

(C) INRA and Springer-Verlag France 2012

\begin{abstract}
Milk fat content and its fatty acid (FA) profile are important components of both the milk nutritional and technological qualities. The present study was conducted to evaluate the influence of calf presence during milking and of cow breed on milk yield, gross composition, FA profile and milk lipolytic system. A total of 30 Prim'Holstein $(\mathrm{PH})$ and Salers $(\mathrm{S})$ primiparous lactating cows were milked in the presence or absence of their calves during 210 days of lactation and bulk milks were collected during 6 weeks in a restricted part of the whole experimental period for analyses. Calf presence increased milk yield and decreased the milk fat content in $\mathrm{S}$ cows, whereas no difference was observed for the PH cows. The PH milk had higher levels of short- and medium-chain FA and C18:2 n-6, whereas S milk had higher levels of C18:2 cis-9,trans-11 (conjugated linoleic acid, CLA), C18:3 n-3 and C20:5 $n-3$. The $\mathrm{S}$ milk also had higher initial lipolysis. Calf presence during milking increased the C16:0 percentage and decreased C18:0, C18:2 n-6, C18:3 n-3, total polyunsaturated FA percentages in milk fat. Calf presence decreased the milk transC18:1 level only in S cows. Cis-9, trans-11-CLA level increased in the calf presence in $\mathrm{PH}$ cows, whereas it decreased in $\mathrm{S}$ cows. Calf presence during milking increased milk lipolysis after $24 \mathrm{~h}$ only in the PH cows. Calf presence during milking had significant effects on the milk yield, gross and fine composition, and lipolysis but these effects differed according to the breed.
\end{abstract}

A. Cozma $\cdot$ B. Martin $\cdot$ M. Guiadeur $\cdot$ E. Tixier $\cdot$ A. Ferlay $(\bowtie)$

INRA, UMR1213 Herbivores, 63122 Saint-Genès-Champanelle, France

e-mail: anne.ferlay@clermont.inra.fr

A. Cozma $\cdot$ B. Martin $\cdot$ M. Guiadeur $\cdot$ E. Tixier $\cdot$ A. Ferlay

VetAgro Sup, UMR Herbivores, BP 10448, 63000 Clermont-Ferrand, France

\footnotetext{
A. Cozma

Faculty of Pharmacy, Department of Environmental Chemistry and Hygiene, Iuliu Hațieganu

University of Medicine and Pharmacy, 6 Pasteur Street, Cluj-Napoca, Romania

P. Pradel

INRA, UE1296, Monts d'Auvergne, 63210 Orcival, France
} 
Prim荷斯坦奶牛和Salers 奶牛泌乳期间牛犊的存在对奶的产量、组成、脂肪酸以及脂解作用 的影响

摘要：乳脂肪含量以及它的脂肪酸组成是衡量奶的营养特性和加工品质很重要的成分。目 前的研究主要是评价不同品种奶牛在泌乳期间小牛犊的存在对产奶量、组成、脂肪酸组成 以及脂解作用的影响。30 Prim 荷斯坦 $(\mathrm{PH})$ Salers初产奶牛 (S) 210天的泌乳期间, 牛犊在 存在或不存在的情况下, 对6个星期在限制的时间内采集的奶进行分析。对于S奶牛而言, 牛 犊的存在增加了产奶量, 但是降低了乳脂肪的含量, 然而对于 $\mathrm{PH}$ 奶牛而言, 牛犊的存在对产 奶量和脂肪含量影响不显著。 $\mathrm{PH}$ 奶牛乳中短链、中链脂肪酸和C18:2 n-6含量较高, 然而 $\mathrm{S}$ 奶牛乳中共轭亚油酸(CLA), 亚麻酸(C18:3 n-3) 和二十碳五稀酸(C20:5 n-3)含量较高。 $S$ 奶牛乳中初始脂解度较高。泌乳期间牛犊的存在增加了乳脂肪中棕榈酸 $(\mathrm{C} 16: 0)$ 的含量, 降 低了硬脂酸 $(\mathrm{C} 18: 0)$, 亚油酸 $(\mathrm{C} 18: 2 \mathrm{n}-6)$, 亚麻酸 $(\mathrm{C} 18: 3 \mathrm{n}-3)$ 和总多不饱和脂肪酸的百分含 量。牛犊的存在只降低了S 奶牛乳中反式油酸(trans-C18:1)的含量。对于 $\mathrm{PH}$ 奶牛, 牛犊的 存在增加了Cis-9, trans-11-CLA的含量, 然而, 对于S奶牛, 牛犊的存在却降低了Cis-9, trans-11-CLA的含量。对于PH奶牛, 泌乳期间牛犊的存在增加了奶在 $24 \mathrm{~h}$ 的脂解作用。两 个奶牛品种至少有一种奶牛在泌乳期间, 牛犊的存在对奶的产量, 组成和脂解作用有影响。

Keywords Calf presence $\cdot$ Cow breed $\cdot$ Milk fatty acids $\cdot$ Lipolytic system

关键词 牛犊存在 ·牛品种. 乳脂肪酸 $\cdot$ 脂解作用

\section{Introduction}

Milk fat content and its fatty acid (FA) profile are important components of milk quality, influencing its transformation into cheese as well as the sensorial and nutritional properties of milk and milk products (Chilliard et al. 2007; Martin et al. 2005). The potential human health benefits of some milk FA have already been identified. Butyric acid (C4:0) is known to exhibit anti-carcinogenic effects (Mills et al. 2011; Shingfield et al. 2008). Medium-chain FA (C8:0-C12:0) may reduce the risk of metabolic syndrome and have also been shown to possess antimicrobial properties (Mills et al. 2011). The isomer cis-9, trans-11 of conjugated linoleic acid (CLA) has demonstrated the ability to prevent various types of cancer, hypertension and atherosclerosis, as well as to improve immune function and bone health in both animal models and in human cells (Bhattacharya et al. 2006; Mills et al. 2011; Shingfield et al. 2008). There is a lack of consistent data in human studies because mixtures of cis9,trans-11 and trans-10,cis-12 isomers of CLA instead of purified cis-9,trans-11 isomer were used.

Diet plays a major role if compared to animal-related factors (species, genotype and breed) in determining variations of the FA composition of milk fat (Chilliard et al. 2007). Few experiments have been conducted comparing Holstein and Jersey breeds (Kelsey et al. 2003; White et al. 2001). In the present experiment, two cow breeds were selected: Prim'Holstein $(\mathrm{PH})$, the main cow breed used for milk production in France, and Salers (S), a dual-purpose breed originating from the northern half of the Massif Central in the Auvergne region of France. Over the past 30 years, Salers breeding has mainly been oriented towards beef production. Currently, the S cows are reared mainly in suckling livestock systems, and no more than $2 \%$ of the French 
population of S cows is still milked. Even though they are marginal in the production of Auvergne milk, the image of S cows is used to promote some local Auvergne PDO cheese varieties, such as Cantal, Salers or Saint-Nectaire cheeses. With approximately 80 farmers located in the Puy de Dôme and Cantal departments of Auvergne, the Salers dairy system is sparse (Institut de l'Elevage 2009), and the S cows have been replaced by more specialised $\mathrm{PH}$ or Montbéliarde cows. The decrease in the number of Salers cows is related to their low production level (2,400 vs. 9,000 kg/lactation for Prim'Holstein) (Institut de l'Elevage 2009) and to the very time-consuming process of milking, referred to as "traditional", that requires the presence of the calf to stimulate milk ejection (Tournadre et al. 2008). A range of studies has focused on breed effect using Holstein, Jersey, Montbéliarde and Normande breeds (Ferlay et al. 2006; Kelsey et al. 2003; White et al. 2001), but few studies were performed on the Salers breed. Moreover, to our knowledge, no previous study has compared the Holstein and Salers breeds.

The available literature indicates that in Bos taurus $\times$ Bos indicus cows, as in $\mathrm{S}$ cows, a reduction in cow-calf contact has a negative effect on milk yield and on the fat content of milked milk (Combellas et al. 2003; Tournadre et al. 2008). Nevertheless, maintaining calf contact during milking considerably increases the time that the farmer must work, so suppressing the contact would simplify the milking routine. Therefore, it is important to analyse whether calf presence vs. calf removal influences milk characteristics, notably cheesemaking, milk protein and fat contents, as well as milk FA profile because this topic is not documented in the literature. Likewise, few studies have been published on the effect of cow-calf contact during milking on the milk lipolytic system. Milk fat lipolysis is the hydrolysis of fat globule triglycerides into free FA (FFA) by milk lipoprotein lipase and endogenous lipases (Ferlay et al. 2006). The development of a rancid flavour in cold stored milk is due to FFA, especially to free butyric acid (Chilliard et al. 2003). Reports have shown that breed has a major influence on the milk lipolytic system in dairy goats, but little information is available for dairy cows (Chilliard et al. 2003).

The objective of this study was to determine the influence of both calf presence and cow breed on milk yield and composition, FA profile and milk lipolytic system.

\section{Materials and methods}

\subsection{Cows and diets}

The study was conducted between October 2009 and June 2010 at the experimental farm of Marcenat - "Institut National de la Recherche Agronomique" (INRA)—-located in a mountainous (1,135-1,215 m above sea level) region of Auvergne (Cantal, France). The duration of the study was 6 weeks from December 14, 2009. A total of $36 \mathrm{PH}$ (38. 11.6 days in milk (DIM) — on December 15, 2009, body weight (BW) - 558.2 kg on average during the lactation period, the interval between the extreme dates of parturitions was 36 days) and S (40.3 \pm 9.4 DIM, BW $613.8 \mathrm{~kg}$ on average, the interval between the extreme dates of parturitions was 36 days) primiparous lactating cows were selected before parturition according to estimated calving date, their potential milk yield (as defined as the best milk yield during an entire lactation of the mother plus the half of the 
best milk yield of the paternal grandmother recorded by the Recording Milk Organisation), BW and body condition score and divided into four groups: one group of $\mathrm{PH}$ cows milked in the presence of the calf (PHCP, $n=6$ ), one group of PH cows milked in the absence of the calf (PHCA, $n=6$ ), one group of S cows milked in the presence of the calf (SCP, $n=9$ ) and one group of S cows milked in the absence of the calf (SCA, $n=15$ ). Among the initial 15 SCA cows, 6 cows dried up before DIM 21 and were excluded from the study, so that the final number of the SCA group was 9.

The cows were housed in five pens and the calves in a separate pen located in the same barn. Immediately after the parturition, the cows were machine-milked twice daily at 0600 and 1530 hours. For the cows milked in the presence of the calf, the mother-calf pair remained together from 24 to $48 \mathrm{~h}$ after calving, with cows being milked at the usual hours. At the end of the second milking, the young returned to the calf pen, and the dam was placed into the cow pen. For these cows, milking included a phase of calf suckling before milking (for about $1 \mathrm{~min}$ ) and then the calf was placed in a pen in front of his mother during milking. Physical contact was allowed, and at the end of milking, the mother-calf pair was placed into a pen, where suckling was allowed until complete emptying of the udder. For the cows milked in the absence of the calf, the newborn calves were separated from their mother immediately after parturition, without any sniffing, licking or suckling.

The total amount of milked milk was recorded individually at each milking by using a continuous milk weighing system. On two consecutive days every week, before suckling and after udder emptying, calves from both the SCP and the PHCP groups were weighed to estimate the amount of suckled milk according to the method described by Le Neindre (1973).

Before calving, the cows were fed collectively with concentrate and $5 \mathrm{~kg}$ dry matter grassland hay (regrowth) after morning milking, while grassland hay was offered ad libitum in the afternoon. The hay was composed of $87 \%$ grasses (essentially $83 \%$ Dactylis glomerata, 2.2\% Elytrigia repens, and $1.2 \%$ ryegrass), and $12.7 \%$ forbs. The regrowth hay was composed of grasses (26\% Poa pratensis, 19\% D. glomerata, 16\% Alopecurus pratensis and 14\% Agrostis capillaris) and 25\% of forbs.

After calving, the animals received the concentrate according to their daily milk production during the morning and afternoon milkings, whereas grassland hay was offered ad libitum. The intake amounts were measured on average from two pens per group. The feedstuffs distributed per pen were weighted daily. Any refusals were collected and weighed daily (4 days each week) to calculate the net intake of each group. The nutritive value was 4.97 MJ of net energy (NE), $80.3 \mathrm{~g}$ PDIE and $75 \mathrm{~g}$ PDIN for the first hay and 4.97 MJ of NE, $105 \mathrm{~g}$ PDIE, $89 \mathrm{~g}$ PDIN for the regrowth hay. The control concentrate contained $26.4 \%$ barley, $20 \%$ wheat bran, $15 \%$ triticale, $10 \%$ rootlets, $5 \%$ wheat, $13.6 \%$ rapeseed meal, $4.8 \%$ sunflower meal, $2 \%$ molasses, $1.5 \%$ rapeseeds and $1.75 \%$ minerals and premix. The nutritive value of the concentrate was $6.96 \mathrm{MJ}$ of $\mathrm{NE}, 2.4 \%$ fat, $7.9 \%$ crude fiber, $15 \%$ crude protein, $116 \mathrm{~g}$ PDIE and $115 \mathrm{~g}$ PDIN and 32.2\% starch. During the experimental period, the $\mathrm{PH}$ and $\mathrm{S}$ cows were fed on average 8.8 and $2.6 \mathrm{~kg}$ of concentrate, respectively. The forage-to-concentrate ratio in the diet was $52 \%$ and $23 \%$ for $\mathrm{PH}$ and $\mathrm{S}$ groups, respectively. The diets were formulated to cover $100 \%$ of the cow energy and protein requirements (Institut National de la Recherche Agronomique INRA 2007). 
Before December 15th, calves were fed only mother's milk. After this date, calves were fed progressively in addition to mother's milk $500 \mathrm{~g}$ concentrate (dry matter basis) formulated to heifer ( $6 \%$ crude fiber and $17 \%$ crude proteins). From April 15 th, they received $1 \mathrm{~kg}$ concentrate (dry matter basis). Hay was offered ad libitum. They were not weaned during the experimental period.

Experimental procedures were approved by the INRA Animal Care and Use Committee and conducted according to French recommendations for the use of experimental animals, including animal welfare and appropriate conditions (Veissier 1999).

\subsection{Milk sampling and analyses}

The bulk morning milk was pooled with the previous evening's milk, which had been stored at $4{ }^{\circ} \mathrm{C}$, for each group, and thus the bulk milks were collected in four separate tanks corresponding to each experimental group on seven dates (December 15, 17 and 21, 2009, and January 6, 11, 13 and 20, 2010). A set of sub-samples (50 mL) was preserved in tubes with bronopol-B2 (Trillaud, Surgères, France) and stored at $4{ }^{\circ} \mathrm{C}$ until analysis for fat, protein, lactose and somatic cell counts using infrared spectrophotometry (Galilait, Theix, France) according to standard procedures (Association of Official Analytical Chemists (AOAC) 1997). The somatic cell count data were logtransformed in order to achieve normality.

A second set of milk sub-samples $(3 \mathrm{~mL})$ was stored at $-20{ }^{\circ} \mathrm{C}$ until the end of the experiment before lyophilisation (Thermovac TM-20, Froilabo, Ozoir-La-Ferrière, France), for analysis of the FA profile. The FA in the lyophilised milk samples were methylated directly according to Ferlay et al. (2010) with some modifications. Briefly, $2 \mathrm{~mL}$ of $0.5 \mathrm{~mol} . \mathrm{L}^{-1}$ sodium methanolate and $1 \mathrm{~mL}$ hexane were mixed with the lyophilised milk at $50{ }^{\circ} \mathrm{C}$ for $15 \mathrm{~min}$, followed by the addition of $1 \mathrm{~mL} 12 \mathrm{~N}$ $\mathrm{HCl} 5 \%$ in methanol $(v / v)$ at $50{ }^{\circ} \mathrm{C}$ for $15 \mathrm{~min}$. The FA methyl esters (FAME) were washed with a saturated $\mathrm{K}_{2} \mathrm{CO}_{3}$ solution and recovered with $1.5 \mathrm{~mL}$ hexane. The FAME were injected $(0.6 \mu \mathrm{L})$ by auto-sampler into a gas chromatograph equipped with a flame ionisation detector (Agilent Technologies 7890A, Wilmington, USA). The FAME from all the samples were separated on a $100 \mathrm{~m} \times 0.25 \mathrm{~mm}$ i.d. fused-silica capillary column (CP-Sil 88, Chrompack, Middelburg, The Netherlands). The injector temperature was maintained at $255^{\circ} \mathrm{C}$ and the detector temperature at $260{ }^{\circ} \mathrm{C}$. The initial oven temperature was held at $70{ }^{\circ} \mathrm{C}$ for $1 \mathrm{~min}$, increased by $5{ }^{\circ} \mathrm{C} / \mathrm{min}$ to $100{ }^{\circ} \mathrm{C}$ (held for $2 \mathrm{~min}$ ), and then increased by $10^{\circ} \mathrm{C} / \mathrm{min}$ to $175^{\circ} \mathrm{C}$ (held for $42 \mathrm{~min}$ ), and $5^{\circ} \mathrm{C} /$ min to a final temperature of $225^{\circ} \mathrm{C}$ (held for $15 \mathrm{~min}$ ). The carrier gas was hydrogen, and constant pressure $(158.6 \mathrm{kPa})$ was maintained during analysis. A reference standard butter (CRM 164, Commission of the European Communities, Community Bureau of Reference, Brussels, Belgium) was used to estimate correction factors for short-chain FA (C4:0 to C10:0). Identification of FAME was accomplished by comparison to a standard mixture purchased from Nu-Chek-Prep, Inc (Elysian, MN 56028 USA). Mixtures of cis/trans (9-12) isomers of linoleic acid methyl ester and cis and trans (9-11) and (10-12) isomers of CLA methyl esters purchased from Sigma-Aldrich Corporation (38297 Saint Quentin Fallavier, France) were used to complete the identification.

A third set of sub-samples was used to evaluate milk lipolysis by determining the initial FFA content and the FFA content after $24 \mathrm{~h}$ of cold storage $\left(4^{\circ} \mathrm{C}\right)$. Immediately 
after sampling, 18-mL samples of milk were taken, heated at $60{ }^{\circ} \mathrm{C}$ for $30 \mathrm{~min}$ to destroy lipase activity and stored at $4{ }^{\circ} \mathrm{C}$ until analysed for initial FFA content (lipolysis at $t_{0}$ ). A second $18-\mathrm{mL}$ sample was stored at $4{ }^{\circ} \mathrm{C}$ for $24 \mathrm{~h}$, then heated and stored at $4{ }^{\circ} \mathrm{C}$ until analysed for FFA content (lipolysis at $t_{24}$ ). The milk lipolytic system was evaluated by the copper soap method (Jellema et al. 1991).

\subsection{Statistical analyses}

Data from individual milks were analysed by variance analysis using the GLM procedure (SAS Institute 2003), with breed (B), treatment (T, presence or absence of the calf during milking) and interaction between breed and treatment $(\mathrm{B} \times \mathrm{T})$ as main effects.

Data for bulk milk composition, FA profile and lipolytic system were analysed by the mixed models procedure of SAS software (SAS Institute 2003) with B, T and B $\times$ T as fixed effects, and cheesemaking dates as random effect. Treatment differences were determined based on $t$ tests and declared significant at $P \leq 0.05$. Trends toward significance were considered at $0.05<P \leq 0.10$.

\section{Results}

\subsection{Milk yield and composition}

Milk yield, milk fat, protein and lactose contents and somatic cell counts are shown in Table 1. During the experimental period, the average milk yield was 26.9 and 11.5 L.day ${ }^{-1}$ for PH and S cows, respectively. The average amount of suckled milk was 4.2 and $5.2 \mathrm{~L} /$ calf/day for $\mathrm{PH}$ and $\mathrm{S}$ cows, respectively. The milked milk represented 84 and $64 \%$ of milk yield for $\mathrm{PH}$ and $\mathrm{S}$ cows, respectively. The milk yield of the SCP group was higher than that of the SCA group, whereas it did not differ between PHCP and PHCA groups $(P<0.05)$.

The SCA group had higher (significant interaction, $P<0.05$ ) milk fat content than the SCP group, whereas no difference $(P<0.05)$ was observed for the PH groups.

The milk protein content was higher for the $\mathrm{S}$ than for the $\mathrm{PH}$ groups $(P<0.01)$. The milk protein content was decreased by the presence of the calf $(P<0.05)$.

Concerning lactose, a significant breed $\times$ treatment effect was found $(P<0.001)$. In the presence of the calf, the lactose tended to decrease $(-2 \%)$ and to increase $(+2 \%)$ for the PH and S cows, respectively.

The presence of the calf only decreased the somatic cell counts in milk from $\mathrm{PH}$ cows (significant interaction, $P<0.01$ ).

\subsection{Milk fatty acid profile}

The milk FA composition is presented in Tables 2 and 3. The milk fat of PH cows had higher percentages of individual saturated FA (SFA) $(\mathrm{C} 4: 0(P<0.01)$, C6:0 $(P<$ 0.001), C7:0 $(P<0.01), \mathrm{C} 8: 0(P<0.001), \mathrm{C} 9: 0(P<0.001), \mathrm{C} 10: 0(P<0.01), \mathrm{C} 11: 0$ $(P<0.001), \mathrm{C} 12: 0(P<0.05)$, anteiso-C17:0 $(P<0.05))$, total monounsaturated FA (MUFA) $(P<0.10)$, and individual MUFA (trans-11-C16:1 $(P<0.01)$, cis-9-C16:1 
Table 1 Influence of cow breed, calf presence during milking, and their interaction on milk yield and composition and milk lipolytic system

\begin{tabular}{|c|c|c|c|c|c|c|c|c|}
\hline & \multicolumn{2}{|l|}{$\mathrm{PH}$} & \multicolumn{2}{|l|}{$\mathrm{S}$} & \multirow[t]{2}{*}{$\mathrm{SEM}^{\mathrm{a}}$} & \multicolumn{3}{|c|}{ Significance $(P \text { value })^{\mathrm{b}}$} \\
\hline & $\mathrm{CP}$ & $\mathrm{CA}$ & $\mathrm{CP}$ & $\mathrm{CA}$ & & $\mathrm{B}$ & $\mathrm{T}$ & $\mathrm{B} \times \mathrm{T}$ \\
\hline Milked milk ${ }^{\mathrm{c}}\left(\right.$ L.day $\left.^{-1}\right)$ & $22.9^{\mathrm{a}}$ & $26.6^{\mathrm{a}}$ & $9.1^{\mathrm{b}}$ & $8.7^{\mathrm{b}}$ & 2.89 & $* * *$ & ns & + \\
\hline Suckled milk ${ }^{\mathrm{c}}\left(\right.$ L.day $\left.^{-1}\right)$ & 4.2 & - & 5.2 & - & 0.78 & $*$ & & \\
\hline Total milk yield ${ }^{\mathrm{c}}\left(\right.$ L.day $\left.^{-1}\right)$ & $27.1^{\mathrm{a}}$ & $26.6^{\mathrm{a}}$ & $14.3^{\mathrm{b}}$ & $8.7^{\mathrm{c}}$ & 2.87 & $* * *$ & $* *$ & $*$ \\
\hline Fat content ${ }^{\mathrm{d}}\left(\mathrm{g} \cdot \mathrm{kg}^{-1}\right)$ & $31.81^{\mathrm{a}}$ & $33.31^{\mathrm{a}}$ & $26.83^{\mathrm{b}}$ & $35.30^{\mathrm{a}}$ & 1.67 & ns & $* * *$ & $*$ \\
\hline Protein content ${ }^{\mathrm{d}}\left(\mathrm{g} \cdot \mathrm{kg}^{-1}\right)$ & 30.08 & 30.84 & 31.58 & 35.04 & 0.95 & $* *$ & $*$ & ns \\
\hline Lactose content ${ }^{\mathrm{d}}\left(\mathrm{g} \cdot \mathrm{kg}^{-1}\right)$ & $52.03^{\mathrm{b}}$ & $53.27^{\mathrm{a}}$ & $53.10^{\mathrm{a}}$ & $52.50^{\mathrm{b}}$ & 0.17 & $\mathrm{~ns}$ & + & $* * *$ \\
\hline Somatic cell counts ${ }^{\mathrm{d}}\left(\log \cdot \mathrm{mL}^{-1}\right)$ & $4.49^{\mathrm{b}}$ & $5.04^{\mathrm{a}}$ & $4.93^{\mathrm{a}}$ & $4.90^{\mathrm{a}}$ & 0.11 & ns & $*$ & $* *$ \\
\hline Lipolysis at $t_{0}^{\mathrm{d}}(\%)$ & 0.79 & 0.66 & 0.84 & 0.83 & 0.04 & $* *$ & + & ns \\
\hline Lipolysis at $t_{24}{ }^{\mathrm{d}}(\%)$ & $0.98^{\mathrm{a}}$ & $0.75^{\mathrm{b}}$ & $0.97^{\mathrm{a}}$ & $0.93^{\mathrm{a}}$ & 0.04 & $*$ & $* *$ & $*$ \\
\hline Lipolysis $_{\Delta 24 h}{ }^{\mathrm{d}}(\%)$ & $0.19^{\mathrm{a}}$ & $0.09^{\mathrm{b}}$ & $0.13^{\mathrm{c}}$ & $0.10^{\mathrm{b}, \mathrm{c}}$ & 0.03 & ns & $* * *$ & $*$ \\
\hline
\end{tabular}

$P H$ Prim'Holstein, $S$ Salers, $C P$ calf present during milking, $C A$ calf absent during milking, $B$ breed (PH or S), $T$ treatment (CP or CA), $B \times T$ breed $\times$ treatment interaction, Lipolysis $\triangle 24 h$ evolution of milk lipolysis after $24 \mathrm{~h}$ (Lipolysis at $t_{0}$-Lipolysis at $t_{24}$ ), SEM standard error of the mean, $n s$ not significant

Within-row means with different letters differ at $P<0.05$

${ }^{a}$ For individual milks, root SEM is presented

${ }^{\mathrm{b}}$ Significance $(P$ value): $\mathrm{ns}, P>0.10 ;+P<0.10 ; * P<0.05 ; * * P<0.01 ; * * * P<0.001$

${ }^{\mathrm{c}}$ Individual milks

${ }^{\mathrm{d}}$ Bulk milks. The number of samples was 7, 7, 7, and 7 for PHCP, PHCA, SCP and SCA groups, respectively

$(P<0.05)$, cis-11-C20:1 $(P<0.001)$, trans-5-C18:1 $(P<0.05)$, trans-6, 8-C18:1 $(P<0.01)$, trans-10-C18:1 $(P<0.001)$, trans-12-C18:1 $(P<0.001)$, trans-13-C18:1 $(P<0.001)$, cis-9C18:1 $(P<0.10)$, cis-11-C18:1 $(P<0.001)$, cis-12-C18:1 $(P<0.001)$, cis-13-C18:1 $(P<0.001)$, cis-14-C18:1 $(P<0.001)$, total cis-C18:1 $(P<0.05)$ and $\mathrm{C} 18: 2 n-6$ $(P<0.001)$ than that of $\mathrm{S}$ cows. In contrast, $\mathrm{PH}$ cows had lower milk fat concentrations of C14:0 $(P<0.10), \mathrm{C} 15: 0(P<0.001)$, anteiso-C15:0 $(P<0.001)$, iso-C16:0 $(P<0.001), \mathrm{C17}: 0(P<0.001)$, iso-C17:0 $(P<0.001)$, cis-9, cis-11-CLA $(P<0.001)$, trans-9,trans-11-CLA $(P<0.05), \mathrm{C} 20: 0(P<0.001), \mathrm{C} 20: 2 n-6(P<0.10), \mathrm{C} 22: 0(P<0.001)$, $\mathrm{C} 20: 5 n-3(P<0.001)$, and $\mathrm{C} 22: 5 n-3(P<0.05)$, if compared to $\mathrm{S}$ cows.

Calf presence during milking increased cis-9-C14:1 $(P<0.001), \mathrm{C} 16: 0(P<0.01)$, cis-9-C16:1 $(P<0.001), \mathrm{C} 17: 0(P<0.10)$, and anteiso-C17:0 $(P<0.001)$ concentrations, whereas it decreased the concentrations of C8:0 $(P<0.10)$, anteiso-C15:0 $(P<$ 0.01), C18:0 $(P<0.05)$, several MUFA (trans-10-C18:1 $(P<0.10)$, trans-13-C18:1 $(P$ $<0.01)$, cis-12-C18:1 $(P<0.05), \mathrm{C} 18: 2 n-6(P<0.001), \mathrm{C} 20(P<0.05), \mathrm{C} 20: 4 n-6(P$ $<0.001), \mathrm{C} 22: 5 n-3(P<0.01)$, and total polyunsaturated FA (PUFA) $(P<0.001)$.

Several significant interactions between cow breed and calf treatment were also observed (Tables 2 and 3). The presence of the calf decreased milk concentrations of cis-14-C18:1 $(P<0.10)$ and C18:3 $n-3(P<0.10)$ more markedly for S than for PH cows. In contrast, the presence of the calf decreased the milk concentration of C20:3 $n-6$ $(P<0.001)$ more markedly for $\mathrm{PH}$ than for S cows. The milk fat $\mathrm{C} 15: 0(P<0.001)$, cis-9, 
Table 2 Influence of cow breed, calf presence during milking, and their interaction on milk FA composition

\begin{tabular}{|c|c|c|c|c|c|c|c|c|}
\hline & \multicolumn{2}{|l|}{$\mathrm{PH}$} & \multicolumn{2}{|l|}{$\mathrm{S}$} & \multirow[t]{2}{*}{ SEM } & \multicolumn{3}{|c|}{ Significance $(P \text { value })^{\mathrm{a}}$} \\
\hline & $\mathrm{CP}$ & $\mathrm{CA}$ & $\mathrm{CP}$ & $\mathrm{CA}$ & & B & $\mathrm{T}$ & $\mathrm{B} \times \mathrm{T}$ \\
\hline \multicolumn{9}{|c|}{ Fatty acid $\left(\mathrm{g} .100 \mathrm{~g}^{-1}\right.$ of FA) ${ }^{\mathrm{b}}$} \\
\hline $\mathrm{C} 4: 0$ & 2.89 & 2.86 & 2.77 & 2.74 & 0.07 & $* *$ & ns & ns \\
\hline $\mathrm{C} 5: 0$ & $0.029^{\mathrm{a}}$ & $0.023^{\mathrm{b}}$ & $0.019^{\mathrm{c}}$ & $0.020^{\mathrm{b}}$ & 0.001 & $* * *$ & ns & $*$ \\
\hline C6:0 & 2.30 & 2.30 & 2.14 & 2.13 & 0.02 & $* * *$ & ns & ns \\
\hline $\mathrm{C} 7: 0$ & 0.02 & 0.02 & 0.02 & 0.02 & 0.001 & $* *$ & ns & ns \\
\hline C8:0 & 1.41 & 1.45 & 1.28 & 1.30 & 0.02 & $* * *$ & + & ns \\
\hline C9:0 & 0.03 & 0.03 & 0.02 & 0.02 & 0.002 & $* * *$ & ns & ns \\
\hline C10:0 & 3.07 & 3.21 & 2.86 & 2.93 & 0.10 & $* *$ & ns & $\mathrm{ns}$ \\
\hline $\mathrm{C} 10: 1$ & 0.26 & 0.25 & 0.25 & 0.24 & 0.01 & + & ns & ns \\
\hline C11:0 & 0.05 & 0.05 & 0.04 & 0.04 & 0.003 & $* * *$ & ns & $\mathrm{ns}$ \\
\hline $\mathrm{C} 12: 0$ & 3.34 & 3.50 & 3.21 & 3.28 & 0.14 & $*$ & ns & ns \\
\hline $\mathrm{C} 12: 1$ & 0.06 & 0.08 & 0.07 & 0.07 & 0.008 & ns & + & + \\
\hline C13:0 & 0.06 & 0.08 & 0.07 & 0.07 & 0.008 & ns & + & + \\
\hline iso-C13:0 & $0.03^{\mathrm{c}}$ & $0.03^{\mathrm{c}}$ & $0.04^{\mathrm{b}}$ & $0.05^{\mathrm{a}}$ & 0.001 & $* * *$ & $* *$ & $*$ \\
\hline anteiso-C13:0 & 0.01 & 0.01 & 0.02 & 0.02 & 0.003 & ns & ns & ns \\
\hline $\mathrm{C} 14: 0$ & 11.12 & 11.12 & 11.44 & 11.32 & 0.35 & + & ns & ns \\
\hline iso-C14:0 & $0.11^{\mathrm{c}}$ & $0.12^{\mathrm{c}}$ & $0.20^{\mathrm{b}}$ & $0.23^{\mathrm{a}}$ & 0.004 & $* * *$ & $* * *$ & $* *$ \\
\hline cis-9-C14:1 & 0.83 & 0.74 & 0.80 & 0.72 & 0.05 & ns & $* * *$ & ns \\
\hline iso-C15:0 & $0.25^{\mathrm{c}}$ & $0.25^{\mathrm{c}}$ & $0.37^{\mathrm{b}}$ & $0.41^{\mathrm{a}}$ & 0.01 & $* * *$ & $* * *$ & $* * *$ \\
\hline anteiso-C15:0 & 0.49 & 0.51 & 0.70 & 0.73 & 0.02 & $* * *$ & $* *$ & ns \\
\hline $\mathrm{C} 15: 0$ & $1.07^{\mathrm{c}}$ & $1.04^{\mathrm{c}}$ & $1.34^{\mathrm{b}}$ & $1.41^{\mathrm{a}}$ & 0.03 & $* * *$ & ns & $* * *$ \\
\hline $\mathrm{C} 16: 0$ & 27.27 & 26.48 & 27.52 & 26.38 & 0.58 & ns & $* *$ & ns \\
\hline iso-C16:0 & 0.27 & 0.27 & 0.45 & 0.49 & 0.01 & $* * *$ & + & ns \\
\hline trans-11-C16:1 & 0.20 & 0.20 & 0.18 & 0.19 & 0.006 & $* *$ & ns & ns \\
\hline cis-9-C16:1 & 1.30 & 1.17 & 1.23 & 1.15 & 0.02 & $*$ & $* * *$ & $\mathrm{~ns}$ \\
\hline cis-11-C16:1 & $0.04^{\mathrm{a}}$ & $0.04^{\mathrm{a}}$ & $0.04^{\mathrm{a}}$ & $0.03^{\mathrm{b}}$ & 0.002 & $* * *$ & $* *$ & $*$ \\
\hline $\mathrm{C} 17: 0$ & 0.71 & 0.70 & 0.80 & 0.78 & 0.01 & $* * *$ & + & ns \\
\hline iso- $\mathrm{C} 17: 0$ & 0.36 & 0.37 & 0.41 & 0.42 & 0.01 & $* * *$ & ns & ns \\
\hline anteiso-C17:0 & 1.30 & 1.17 & 1.23 & 1.15 & 0.02 & $*$ & $* * *$ & ns \\
\hline C18:0 & 10.34 & 10.91 & 10.44 & 10.58 & 0.43 & ns & $*$ & ns \\
\hline iso-C18:0 & $0.06^{\mathrm{b}}$ & $0.07^{\mathrm{b}}$ & $0.08^{\mathrm{a}}$ & $0.07^{\mathrm{b}}$ & 0.003 & $*$ & ns & $*$ \\
\hline cis-9,trans-13-C18:2 & 0.14 & 0.15 & 0.13 & 0.14 & 0.008 & ns & $\mathrm{ns}$ & ns \\
\hline trans-11,cis-15-C18:2 & $0.08^{\mathrm{c}}$ & $0.07^{\mathrm{c}}$ & $0.11^{\mathrm{b}}$ & $0.13^{\mathrm{a}}$ & 0.007 & $* * *$ & ns & $*$ \\
\hline $\mathrm{C} 20: 0$ & 0.17 & 0.17 & 0.20 & 0.21 & 0.006 & $* * *$ & $*$ & ns \\
\hline cis-11-C20:1 & 0.07 & 0.07 & 0.05 & 0.06 & 0.004 & $* * *$ & ns & ns \\
\hline cis-9,trans-11-CLA & $0.57^{\mathrm{c}}$ & $0.53^{\mathrm{d}}$ & $0.86^{\mathrm{b}}$ & $0.90^{\mathrm{a}}$ & 0.03 & $* * *$ & ns & $* * *$ \\
\hline cis-9,cis-11-CLA & 0.05 & 0.04 & 0.07 & 0.07 & 0.006 & $* * *$ & ns & ns \\
\hline trans-11,trans-13-CLA & 0.03 & 0.03 & 0.03 & 0.02 & 0.003 & ns & $\mathrm{ns}$ & ns \\
\hline trans-9,trans-11-CLA & 0.03 & 0.02 & 0.03 & 0.03 & 0.003 & $*$ & ns & ns \\
\hline
\end{tabular}


Table 2 (continued)

\begin{tabular}{|c|c|c|c|c|c|c|c|c|}
\hline & \multicolumn{2}{|l|}{$\mathrm{PH}$} & \multicolumn{2}{|l|}{$\mathrm{S}$} & \multirow[t]{2}{*}{ SEM } & \multicolumn{3}{|c|}{ Significance $(P \text { value })^{\mathrm{a}}$} \\
\hline & $\mathrm{CP}$ & $\mathrm{CA}$ & $\mathrm{CP}$ & $\mathrm{CA}$ & & $\mathrm{B}$ & $\mathrm{T}$ & $\mathrm{B} \times \mathrm{T}$ \\
\hline $\mathrm{C} 18: 2 n-6$ & 2.00 & 2.13 & 1.43 & 1.54 & 0.09 & $* * *$ & $* * *$ & ns \\
\hline $\mathrm{C} 18: 3 n-3$ & 0.82 & 0.85 & 0.91 & 1.00 & 0.02 & $* * *$ & $* * *$ & + \\
\hline $\mathrm{C} 20: 2 n-6$ & 0.03 & 0.04 & 0.04 & 0.04 & 0.003 & + & $\mathrm{ns}$ & ns \\
\hline $\mathrm{C} 22: 0$ & 0.07 & 0.06 & 0.10 & 0.10 & 0.004 & $* * *$ & ns & ns \\
\hline $\mathrm{C} 20: 3 n-6$ & 0.07 & 0.09 & 0.07 & 0.08 & 0.003 & ns & $* * *$ & + \\
\hline $\mathrm{C} 20: 4 n-6$ & 0.11 & 0.12 & 0.12 & 0.12 & 0.003 & ns & $* * *$ & ns \\
\hline $\mathrm{C} 20: 5 n-3$ & 0.07 & 0.07 & 0.08 & 0.08 & 0.003 & $* * *$ & ns & ns \\
\hline $\mathrm{C} 22: 5 n-3$ & 0.13 & 0.16 & 0.16 & 0.17 & 0.01 & $*$ & $* *$ & ns \\
\hline $\mathrm{C} 22: 6 n-3$ & 0.02 & 0.02 & 0.02 & 0.02 & 0.002 & ns & ns & ns \\
\hline Total SFA & 64.19 & 64.26 & 64.57 & 63.63 & 0.79 & ns & ns & ns \\
\hline Total OBCFA & $4.88^{\mathrm{c}}$ & $4.77^{\mathrm{d}}$ & $5.82^{\mathrm{b}}$ & $5.94^{\mathrm{a}}$ & 0.10 & $* * *$ & ns & $* *$ \\
\hline Total MUFA & 27.60 & 27.45 & 26.46 & 27.03 & 0.72 & + & ns & ns \\
\hline Total trans FA & $4.36^{\mathrm{c}}$ & $4.31^{\mathrm{c}}$ & $4.77^{\mathrm{b}}$ & $5.04^{\mathrm{a}}$ & 0.22 & $* * *$ & + & $*$ \\
\hline Total PUFA & 4.38 & 4.55 & 4.29 & 4.60 & 0.13 & ns & $* * *$ & ns \\
\hline Total CLA & $0.68^{\mathrm{c}}$ & $0.62^{\mathrm{d}}$ & $0.99^{\mathrm{b}}$ & $1.03^{\mathrm{a}}$ & 0.03 & $* * *$ & ns & $* * *$ \\
\hline Short-chain FA & 13.41 & 13.72 & 12.62 & 12.73 & 0.25 & $* * *$ & ns & ns \\
\hline Medium-chain FA & 45.09 & 44.08 & 46.68 & 45.42 & 1.07 & $* *$ & * & ns \\
\hline Long-chain FA & 41.92 & 42.71 & 40.53 & 41.77 & 1.45 & * & + & ns \\
\hline \multicolumn{9}{|l|}{ Desaturase ratio } \\
\hline cis-9-C14:1/C14 :0 & 0.07 & 0.06 & 0.07 & 0.06 & 0.003 & $*$ & $* * *$ & $\mathrm{~ns}$ \\
\hline cis-9-C16:1/C16 :0 & 0.02 & 0.02 & 0.02 & 0.02 & 0.001 & ns & ns & + \\
\hline cis-9-C18:1/C18:0 & 2.02 & 1.91 & 1.91 & 1.93 & 0.04 & + & * & $\mathrm{ns}$ \\
\hline cis-9,trans-11-CLA/cis-9-C18:1 & $0.027^{\mathrm{a}}$ & $0.025^{\mathrm{b}}$ & $0.043^{\mathrm{c}}$ & $0.044^{\mathrm{c}}$ & 0.001 & $* * *$ & ns & $* *$ \\
\hline
\end{tabular}

$P H$ Prim'Holstein, $S$ Salers, $C P$ calf present during milking, $C A$ calf absent during milking, $B$ breed (PH or $\mathrm{S}), T$ treatment (CP or CA), $B \times T$ breed $\times$ treatment interaction, $S E M$ standard error of the mean, $n s$ not significant, $C L A$ conjugated linoleic acid, SFA saturated FA, OBCFA odd- and branched-chain FA, MUFA monounsaturated FA, PUFA polyunsaturated FA, short-chain FA from C4:0 to C12:0, medium-chain FA from C13:0 to cis-9-C17:1, long-chain FA from C18:0 to C22:6 n-3

Within-row means with different letters differ at $P<0.05$.

${ }^{a}$ Significance $(P$ value): ns, $P>0.10 ;+P<0.10 ; * P<0.05 ; * * P<0.01 ; * * * P<0.001$

${ }^{\mathrm{b}}$ The number of samples were 7, 7, 7, and 7 for PHCP, PHCA, SCP and SCA groups, respectively

trans-11-CLA $(P<0.001)$, total CLA $(P<0.001)$, total odd- and branched-chain FA (OBCFA) $(P<0.01)$ concentrations were decreased with $\mathrm{S}$ cows in the presence of the calf, whereas they were increased with $\mathrm{PH}$ cows. In contrast, iso-C18:0 concentration did not change in the presence of the calf with $\mathrm{PH}$ cows and increased with $\mathrm{S}$ cows. In the case of iso-C13:0 $(P<0.05)$, iso-C15:0 $(P<0.001)$, iso-C14:0 $(P<0.01)$ (Table 2), trans-9-C18:1 $(P<0.01)$ (Table 3), trans-11-C18:1 $(P<0.05)$, trans-12-C18:1 $(P<0.10)$, total trans-C18:1 $(P<0.05)$, trans-11,cis-15-C18:2 $(P<0.05)$, and total trans FA $(P<$ 0.05 ) (Table 2), the presence of the calf produced a decrease in their concentrations only with $\mathrm{S}$ cows. In a similar manner, the presence of the calf increased C5:0 $(P<0.05)$ and 
Table 3 Influence of cow breed, calf presence during milking, and their interaction on concentrations of trans and cis isomers of 18:1 in milk fat

\begin{tabular}{|c|c|c|c|c|c|c|c|c|}
\hline & \multicolumn{2}{|l|}{$\mathrm{PH}$} & \multicolumn{2}{|l|}{$\mathrm{S}$} & \multirow[t]{2}{*}{ SEM } & \multicolumn{3}{|c|}{ Significance $(P \text { value })^{\mathrm{a}}$} \\
\hline & $\mathrm{CP}$ & $\mathrm{CA}$ & $\mathrm{CP}$ & $\mathrm{CA}$ & & $\mathrm{B}$ & $\mathrm{T}$ & $\mathrm{B} \times \mathrm{T}$ \\
\hline \multicolumn{9}{|c|}{ Fatty acid $\left(\mathrm{g} .100 \mathrm{~g}^{-1}\right.$ of FA) ${ }^{\mathrm{b}}$} \\
\hline trans-4-C18:1 & 0.02 & 0.02 & 0.02 & 0.01 & 0.002 & ns & ns & ns \\
\hline trans-5-C18:1 & 0.02 & 0.02 & 0.01 & 0.01 & 0.002 & $*$ & ns & ns \\
\hline trans-6,8-C18:1 & 0.25 & 0.25 & 0.23 & 0.24 & 0.02 & $* *$ & $\mathrm{~ns}$ & ns \\
\hline trans-9-C18:1 & $0.21^{\mathrm{a}}$ & $0.21^{\mathrm{a}}$ & $0.19^{\mathrm{b}}$ & $0.21^{\mathrm{a}}$ & 0.009 & $*$ & + & $* *$ \\
\hline trans-10-C18:1 & 0.30 & 0.31 & 0.18 & 0.20 & 0.02 & $* * *$ & + & ns \\
\hline trans-11-C18:1 & $1.40^{\mathrm{b}}$ & $1.42^{\mathrm{b}}$ & $1.89^{\mathrm{a}}$ & $1.96^{\mathrm{a}}$ & 0.11 & $* * *$ & ns & $*$ \\
\hline trans-12-C18:1 & 0.25 & 0.25 & 0.18 & 0.21 & 0.02 & $* * *$ & * & + \\
\hline trans-13-C18:1 & 0.46 & 0.49 & 0.33 & 0.39 & 0.02 & $* * *$ & $* *$ & ns \\
\hline Sum of trans-C18:1 & $2.97^{\mathrm{b}}$ & $2.98^{\mathrm{b}}$ & $3.05^{\mathrm{b}}$ & $3.26^{\mathrm{a}}$ & 0.18 & $* * *$ & $*$ & $*$ \\
\hline cis-9-C18:1 & 20.86 & 20.82 & 19.90 & 20.30 & 0.61 & + & $\mathrm{ns}$ & ns \\
\hline cis-11-C18:1 & 0.74 & 0.75 & 0.58 & 0.60 & 0.02 & $* * *$ & ns & ns \\
\hline$c i s-12-\mathrm{C} 18: 1$ & 0.16 & 0.17 & 0.09 & 0.12 & 0.02 & $* * *$ & $*$ & ns \\
\hline cis-13-C18:1 & 0.09 & 0.08 & 0.05 & 0.06 & 0.006 & $* * *$ & ns & ns \\
\hline cis-14-C18:1 & 0.25 & 0.26 & 0.21 & 0.24 & 0.01 & $* * *$ & $* * *$ & + \\
\hline Sum of cis-C18:1 & 22.11 & 22.10 & 20.84 & 21.32 & 0.65 & $*$ & ns & ns \\
\hline
\end{tabular}

$P H$ Prim'Holstein; $S$ Salers; $C P$ calf present during milking; $C A$ calf absent during milking; $B$ breed $(\mathrm{PH}$ or $\mathrm{S})$; $T$ treatment $(\mathrm{CP}$ or $\mathrm{CA}) ; B \times T$ breed $\times$ treatment interaction; $S E M$ standard error of the mean; $n s$ not significant

Within-row means with different letters differ at $P<0.05$

${ }^{a}$ Significance $(P$ value): ns, $P>0.10 ;+P<0.10 ; * P<0.05 ; * * P<0.01 ; * * * P<0.001$

${ }^{\mathrm{b}}$ The number of samples were 7, 7, 7, and 7 for PHCP, PHCA, SCP and SCA groups, respectively

decreased $\mathrm{C} 12: 1(P<0.10)$ and $\mathrm{C} 13: 0(P<0.10)$ concentrations with PH cows, but had no influence on these FA concentrations with $\mathrm{S}$ cows.

\subsection{Milk lipolysis}

Initial lipolysis was more important $(P<0.01)$ in the milk of $\mathrm{S}$ cows than in the milk of PH cows. The presence of the calf tended to increase the initial lipolysis $(P<0.10$, Table 1). The presence of the calf only increased the lipolysis measured after $24 \mathrm{~h}$ for the $\mathrm{PH}$ cows $(P<0.01)$

\section{Discussion}

\subsection{Milk yield and composition}

The average milk yield of each breed during the experimental period highlighted a large difference in production potential between the two cow breeds. Our results are 
in agreement with data provided by the Institut de l'Elevage (2009), reporting a milk yield of $8,396 \mathrm{~kg} /$ lactation for $\mathrm{PH}$ primiparous cows vs. 1,954 $\mathrm{kg} / \mathrm{lactation}$ for $\mathrm{S}$ primiparous cows. The difference in milk yield between the $\mathrm{PH}$ and $\mathrm{S}$ breeds is the result of a long selection process for milk productivity and thus could induce a difference in the size of the mammary cisterns, animals with large cisterns such as $\mathrm{PH}$ cows being more efficient milk producers (Ayadi et al. 2003).

The more significant decrease $(P<0.05)$ in total milk yield without the calf for the $\mathrm{S}$ than for the PH groups could be a consequence of a highly developed maternal instinct in S cows (Tournadre et al. 2008). For PH group, our results are in agreement with Bar-Peled et al. (1998) using Holstein cows milked three times daily compared to Holstein cows milked and suckled three times for a 6 -week postpartum period. Our results agree also with Tesorero et al. (2001), showing that Brahman $\times$ Holstein cows milked in the absence of their calves produced less milk $(-2 \mathrm{~kg} /$ day $)$ than cows for which suckling was allowed before each milking. Likewise, Sidibé-Anago et al. (2008) observed in a study with Zebu cows, that the longer the suckling period was, the higher was the total milk yield. The increasing milk yield of cows milked in the presence of the calf could be due to higher milk synthesis by the mammary gland as a result of higher udder stimulation, initiating oxytocin release and therefore milk ejection during suckling (McKusick et al. 2002; Tournadre et al. 2008). In contrast, De Passillé et al. (2008) reported no difference with or without the calf during milking in Holstein cows and concluded that there is no obvious advantage for milk production in keeping the calf with the cow.

Milk fat content was decreased in the presence of the calf, in agreement with Mendoza et al. (2010), who observed in similar experiments on Holstein cows, a decrease of approximately $22 \%$ in the fat content for cows milked in the presence of the calf. This could be explained by the fact that when a calf empties the udder after the milking, it drinks the residual milk (the alveolar milk), having a higher fat content, and therefore causes a decrease in the fat content of the milked milk (corresponding to the cisternal milk) (Fröberg et al. 2008; Ontsouka et al. 2003). In disagreement with our results, McKusick et al. (2002) using East Friesian dairy ewes provided evidence that there is a reduction in the amount of milk fat transferred from the alveoli to the cistern when ewes were separated from their lambs. Moreover, this decrease in milk fat content in the presence of the calf is observed only with S cows. One explanation could be due to the fact that the cistern of udder from $\mathrm{S}$ cows has a lower volume than that from $\mathrm{PH}$ cows. Thus, the cisternal milk to the alveolar milk ratio is weaker for $\mathrm{S}$ cows and explains this strong decrease.

The $\mathrm{PH}$ groups when compared to the S groups had lower milk protein content, in agreement with data recorded in the farms (Institut de l'Elevage 2009).

Moreover, the presence of the calf decreased milk protein content for the $\mathrm{S}$ groups and numerically for the $\mathrm{PH}$ cows. This decrease might be attributed to a dilution effect, linked to higher milk productivity of $\mathrm{S}$ cows in the presence of the calf. Our results are in disagreement with Fröberg et al. (2008) using Holstein cows, showing that suckled milk had lower protein content, whereas Mendoza et al. (2010) reported no significant influence of the presence or absence of the calf on milk protein content in Holstein cows. Similarly, with dairy ewes, McKusick et al. (2002) reported no inhibition on the transfer of milk protein from the alveoli to the cistern when the ewes were separated from their lambs. 
Milk lactose content tended to be decreased by the presence of the calf for the $\mathrm{PH}$ group, whereas it increased for the $\mathrm{S}$ group. For the $\mathrm{PH}$ group, this effect may be partly due to a dilution of milk because milk yield increased in the presence of the calf. Our results are in agreement with Ontsouka et al. (2003) showing lactose concentration is higher in the milk alveolar fraction, suckled by the calf, than in the cisternal fraction. In contrast, Tournadre et al. (2008) reported no significant influence of $\mathrm{S}$ calf presence or absence during milking on milk lactose content.

Somatic cell counts in milk from PH cows decreased in the presence of the calf. Fröberg et al. (2008) showed a decrease in somatic cell counts, when calf suckling was allowed, possibly due to better udder emptying or due to bacterial inhibitors present in calf saliva. One hypothesis concerning this interaction could be linked to an udder easier to be milked for $\mathrm{PH}$ cows than for S cows but this hypothesis should be validated on individual data.

\subsection{Milk fatty acid profile}

The cow breed had a significant effect on the concentrations of several FA in milk fat. Nevertheless, in this study, we must be careful in the interpretation of the results because the effect of breed is confounded with the composition of the diet, particularly the forage-to-concentrate ratio. The influence of breed on milk FA composition has already been reported in previous studies (Ferlay et al. 2006; Kelsey et al. 2003; White et al. 2001). A higher concentration of C4:0 and a slightly lower concentration of C14:0 in milk fat from Holstein cows compared to Montbéliarde cows have also been reported by Ferlay et al. (2010). In agreement with Ferlay et al. (2010), but in disagreement with Lawless et al. (1999) and Ferlay et al. (2006), breed had no effect on the milk fat percentage of C16:0 in our study. Moreover, we observed no effect of breed on C18:0 concentration, whereas Lawless et al. (1999) obtained a higher C18:0 concentration in milk fat from Normande and Montbéliarde cows than in that from Holstein cows.

Breed had no effect on cis-9-C14:1 in our study, whereas Ferlay et al. (2010) reported higher concentrations of cis-9-C14:1, cis-9-C18:1, cis-9,trans-11-CLA and cis-9,cis-11-CLA in milk fat from Holstein cows than in milk fat from Montbéliarde cows. Nevertheless, in accordance with this latter study: cis-9, trans-11-CLA $\left(+0.33\right.$ g.100 $\left.\mathrm{g}^{-1}\right)$ and cis-9,cis-11-CLA $\left(+0.03\right.$ g. $\left.100 \mathrm{~g}^{-1}\right)$ concentrations were higher in milk fat from $\mathrm{S}$ cows than from $\mathrm{PH}$ cows, whereas cis-9-C16:1 concentration was higher in milk fat from $\mathrm{PH}$ cows than in milk fat from $\mathrm{S}$ cows. A small influence of cow breed on milk cis-9,trans-11-CLA content has already been reported by Lawless et al. (1999) (+0.36 g.100 $\mathrm{g}^{-1}$ of FA; Montbéliarde $>$ Dutch Holstein/Friesian), White et al. (2001) (+0.10 g.100 g $\mathrm{g}^{-1}$; Holstein $>$ Jersey) and Kelsey et al. (2003) (+0.03 g.100 g $\mathrm{g}^{-1}$; Holstein >Brown Swiss).

A higher milk concentration of cis-9,trans-11-CLA for the S breed than for the PH breed could be partly explained by increased activity of stearoyl coenzyme-A desaturase (SCD), as suggested by the higher desaturase ratio (cis-9, trans-11-CLA/cis-9C18:1) for the $\mathrm{S}$ breed than for the PH breed. In fact, up to $90 \%$ of the cis-9,trans-11CLA in bovine milk is formed from the activity of this enzyme in the mammary gland (Arnould and Soyeurt 2009). Increasing milk cis-9,trans-11-CLA by increasing the activity of the SCD could be considered a possibility for improving the nutritional quality of milk. 
The higher milk concentration of OBCFA for the $\mathrm{S}$ breed could be due to the diet rich in forage distributed to the $\mathrm{S}$ cows. In fact, diets based on grass forage and rich in fiber could enhance the milk concentration of these FA (Chilliard et al. 2007).

Treatment also had a significant influence on milk FA concentrations. For most FA, essentially FA with 18 atoms of carbon and total PUFA, the presence of the calf decreased their concentrations in milk fat, likely due to the milk richer in fat being suckled by the calf (Fröberg et al. 2008; Ontsouka et al. 2003).

Concerning the influence of calf presence on milk C18:1 isomer concentrations, our results are in agreement with McKusick et al. (2002), showing that C18:1 concentration tended to be higher in the alveolar milk fraction compared to the cisternal milk fraction. In disagreement with our results, this latter study showed no significant difference between alveolar and cisternal milk fractions in the concentrations of C8:0, C14:1, C16:0, C16:1, C18:0, C18:2, C18:3 and C20:0, but also for $\mathrm{C} 4: 0, \mathrm{C} 6: 0, \mathrm{C} 10: 0, \mathrm{C} 12: 0$ and $\mathrm{C} 14: 0$, for which we observed no variation with respect to calf presence.

In our study, we only observed a decrease in the concentrations of the intermediates of ruminal biohydrogenation (trans-9-C18:1, trans-11-C18:1, trans-12-C18:1, total trans-C18:1, cis-14-C18:1, trans-11,cis-15-C18:2 and cis-9,trans-11-CLA) in the milk of $\mathrm{S}$ cows when the calf was present. This could be because the ruminal biohydrogenation may be less complete in $\mathrm{S}$ than in PH cows. This fact could be explained by a lower ruminal fluid retention with a diet poor in concentrate (Chilliard et al. 1995).

\subsection{Milk lipolysis}

In our study, initial lipolysis was more important in the milk of S cows than in the milk of PH cows. This could be partly explained by the negative correlations between milk lipolysis and milk yield found by Chazal and Chilliard (1986). Our results are in disagreement with Ferlay et al. (2006) who noted lower initial lipolysis with Tarentaise cows than with Montbéliarde cows. The Tarentaise breed produced less milk than the Montbéliarde breed. Nevertheless, Chazal and Chilliard (1987) reported no difference in milk lipolysis between Friesian and Montbéliarde cows having different milk yields.

The high lipolysis in the present experiment could also be due to the cow parity. The study was performed on primiparous cows, and Chilliard and Lamberet (1984) reported that lipolysis seems to be higher in primiparous than in multiparous cows.

The initial lipolysis, as well as the lipolysis measured after $24 \mathrm{~h}$, was increased by the presence of the calf. This is contradictory to results obtained by Tournadre et al. (2008), that showed for S cows that the weaker the contact between cow and calf, the greater the lipolysis after $24 \mathrm{~h}$.

\section{Conclusions}

The present study reported a significant effect of cow breed on milk yield, milk protein content, FA composition and initial lipolysis. The milk from $\mathrm{S}$ cows had higher protein content than that from $\mathrm{PH}$ cows, which could create some difficulties during cheesemaking for $\mathrm{PH}$ cows' milk. It seems that $\mathrm{S}$ cows produced milk richer in FA of nutritional interest (C18:3n-3, C20:5 n-3, C22:5n-3 and cis-9,trans-11-CLA) than 
did PH cows. Nevertheless, concerning lipolysis, milk from S cows had a higher level of initial FFA than milk from PH cows, suggesting that it may develop a rancid flavour.

Our study is the first to analyse the influence of calf presence during milking on milk yield, gross composition, FA profile and lipolysis. The presence of the calf during milking only increased total milk yield, and decreased the milk fat content only in $\mathrm{S}$ cows, and increased lipolysis at $t_{24}$ only in PH cows, suggesting that the presence of the calf during milking could have an influence on the organoleptic characteristics of the milk. The presence of the calf also increased the milk concentration of $\mathrm{C} 16: 0$ and decreased the milk C18:0, C18:2 n-6, C18:3n-3 and total PUFA concentrations for the two breeds. Further investigations using individual milk samples will be needed in order to confirm these results.

Acknowledgments The authors thank the technical staff of UEMA for animal care, and J Agabriel (INRA) and B Faure (Groupe Salers Evolution) who managed the PSDR (Pour et Sur le Développement Régional) program 2007-2011 that supported this research and the European Social Fund-project 88/1.5/S/56949.

\section{References}

Arnould VM-R, Soyeurt H (2009) Genetic variability of milk fatty acids. J Appl Genet 50:29-39

Association of Official Analytical Chemists (AOAC) (1997) Official methods of analysis, 16th edn. AOAC, Gaithersburg, MD, USA

Ayadi M, Caja G, Such X, Knight CH (2003) Use of ultrasonography to estimate cistern size and milk storage at different milking intervals in the udder of dairy cows. J Dairy Res 70:1-7

Bar-Peled U, Aharoni Y, Robinzon B, Bruckental I, Lehrer R, Maltz E, Knight C, Kali J, Folman Y, Voet H, Gacitua H, Tagari H (1998) The effect of enhanced milk yield of dairy cows by frequent milking or suckling on intake and digestibility of the diet. J Dairy Sci 81:1420-1427

Bhattacharya A, Banu J, Rahman M, Causey J, Fernandes G (2006) Biological effects of conjugated linoleic acids in health and disease. J Nutr Biochem 17:789-810

Chazal MP, Chilliard Y (1986) Effect of stage of lactation, stage of pregnancy, milk yield and herd management on seasonal variation in spontaneous lipolysis in bovine milk. J Dairy Res 53:529-538

Chazal MP, Chilliard Y (1987) Effect of breed of cow (Friesian and Montbéliarde) on spontaneous and induced lipolysis in milk. J Dairy Res 54:7-11

Chilliard Y, Doreau M, Bocquier F, Lobley GE (1995) Digestive and metabolic adaptations of ruminants to variations in food supply. In: M Journet, E Grenet, MH Farce, M Thériez, C Demarquilly, (eds), Recent developments in the Nutrition of Herbivores. Proceedings of the IVth International Symposium on the Nutrition of Herbivore, 329-360. INRA Editions, Paris. 329-360

Chilliard Y, Ferlay A, Rouel J, Lamberet G (2003) A review of nutritional and physiological factors affecting goat milk lipid synthesis and lipolysis. J Dairy Sci 86:1751-1770

Chilliard Y, Glasser F, Ferlay A, Bernard L, Rouel J, Doreau M (2007) Diet, rumen biohydrogenation and nutritional quality of cow and goat milk fat. Eur J Lipid Sci Tech 109:828-855

Chilliard Y, Lamberet G (1984) La lipolyse dans le lait: les différents types, mécanismes, facteurs de variation, signification pratique [Milk lipolysis: types, mechanisms, variation factors, practical significance]. Lait 64:544-578

Combellas J, Tesorero M, Gabaldón L (2003) Effect of calf stimulation during milking on milk yield and fat content of Bos indicus $\times$ Bos taurus cows. Livest Prod Sci 79:227-232

Ferlay A, Martin B, Lerch S, Gobert M, Pradel P, Chilliard Y (2010) Effects of supplementation of maize silage diets with extruded linseed, vitamin $\mathrm{E}$ and plant extracts rich in polyphenols, and morning $v$. evening milking on milk fatty acid profiles in Holstein and Montbéliarde cows. Animal 4:627-640

Ferlay A, Martin B, Pradel P, Coulon JB, Chilliard Y (2006) Influence of grass-based diets on milk fatty acid composition and milk lipolytic system in Tarentaise and Montbéliarde cow breeds. J Dairy Sci 89:4026-4041

Fröberg S, Gratte E, Svennersten-Sjaunja K, Olsson I, Berg C, Orihuela A, Galina CS, García B, Lidfors L (2008) Effect of suckling ('restricted suckling') on dairy cows' udder health and milk let-down and their calves' weight gain, feed intake and behaviour. Appl Anim Behav Sci 113:1-14 
Institut de l'Elevage (2009) France. http://www.inst-elevage.asso.fr/IMG/pdf_Partie_bovine_CL_2009.pdf. Accessed 28 Dec 2011

Institut National de la Recherche Agronomique (INRA) (2007) Alimentation des bovins, ovins et caprins. Besoins des Animaux - Valeur des aliments - Tables [Cattle, sheep and goat nutrition. Recommended allowances - feed tables]. Quae Editions, Versailles, France

Jellema A, Anderson M, Heeschen W, Kuzdzal Savoie S, Needs EC, Suhren G, Van Reusel A (1991) Determination of free fatty acids in milk and milk products. Bull Int Dairy Fed, Vol. 265. Int Dairy Fed, Brussels, Belgium

Kelsey JA, Corl BA, Collier RJ, Bauman DE (2003) The effect of breed, parity, and stage of lactation on conjugated linoleic acid (CLA) in milk fat from dairy cows. J Dairy Sci 86:2588-2597

Lawless F, Stanton C, L'Escop P, Devery R, Dillon P, Murphy JJ (1999) Influence of breed on bovine milk cis-9, trans-11-conjugated linoleic acid content. Livest Prod Sci 62:43-49

Le Neindre P (1973) Observations sur l'estimation de la production laitière des vaches allaitantes par la pesée du veau avant et après la tétée. [Observations on the estimation of milk production in lactating cows by weighing the calf before and after suckling]. Ann Zootech 22:413-422

Martin B, Verdier-Metz I, Buchin S, Hurtaud C, Coulon JB (2005) How do the nature of forages and pasture diversity influence the sensory quality of dairy livestock products? Anim Sci 81:205-212

McKusick BC, Thomas DL, Romero JE, Marnet PG (2002) Effect of weaning system on milk composition and distribution of milk fat within the udder of East Friesian dairy ewes. J Dairy Sci 85:2521-2528

Mendoza A, Cavestany D, Roig G, Ariztia J, Pereira C, La Manna A, Contreras DA, Galina CS (2010) Effect of restricted suckling on milk yield, composition and flow, udder health, and postpartum anoestrus in grazing Holstein cows. Livest Sci 127:60-66

Mills S, Ross RP, Hill C, Fitzgerald GF, Stanton C (2011) Milk intelligence: mining milk for bioactive substances associated with human health. Int Dairy J 21:377-401

Ontsouka CE, Bruckmaier RM, Blum JW (2003) Fractionized milk composition during removal of colostrum and mature milk. J Dairy Sci 86:2005-2011

De Passillé AM, Marnet PG, Lapierre H, Rushen J (2008) Effects of twice-daily nursing on milk ejection and milk yield during nursing and milking in dairy cows. J Dairy Sci 91:1416-1422

Shingfield KJ, Chilliard Y, Toivonen V, Kairenius P, Givens DI (2008) Trans fatty acids and bioactive lipids in ruminant milk. Adv Exp Med Biol 606:3-65

Sidibé-Anago AG, Ouédraogo GA, Ledin I (2008) Effect of suckling period on calf growth and milk yield of Zebu cows. Trop Anim Health Prod 40:491-499

Statistical Analysis System Institute (2003) SAS/STAT User's guide. SAS Inst, Cary, NC, USA

Tesorero M, Combellas J, Uzcátegui W, Gabaldón L (2001) Influence of suckling before milking on yield and composition of milk from dual purpose cows with restricted suckling. Livest Res Rural Dev 13. http://www.lrrd.org/lrrd13/1/teso131.htm. Accessed 27 Jan 2012

Tournadre H, Veissier I, Martin B, Garel JP (2008) Influence of cow-calf contact before milking and mother-young relationship on yield and composition of milk in Salers cows. Renc Rech Ruminants 15:159-162

Veissier I (1999) Expérimentation animale: Biologie, éthique, réglementation [Animal experimentation: biology, ethics, regulation]. INRA Prod Anim 12:365-375

White SL, Bertrand JA, Wade MR, Washburn SP, Green JT Jr, Jenkins TC (2001) Comparison of fatty acid content of milk from Jersey and Holsein cows consuming pasture or a total mixed ration. J Dairy Sci $84: 2295-2301$ 